\title{
Part Dosing Unit
}

National Cancer Institute

\section{Source}

National Cancer Institute. Part Dosing Unit. NCI Thesaurus. Code C48522.

A fraction of a dosing unit. 